\title{
Research on Application of Brand building of Chiang Ma Yuan Recreational Farm Area
}

\author{
${ }^{1}$ Yu, Yung-Hsun, ${ }^{2}$ Lo, Chih-Yao, ${ }^{3}$ Hou, Cheng-I, ${ }^{4 \star}$ Lee, Ta-Sheng \\ ${ }^{1}$ Assis Prof., Department. of Tourism and Leisure Management, St. John's University \\ 1 yyh@mail.sju.edu.tw \\ 2 Prof., Department of Information Management, Yu Da University of Science and Technology \\ 2jacklo@ydu.edu.tw \\ ${ }^{3}$ Assoc. Prof., Department of Leisure Management, Yu Da University of Science and Technology \\ ${ }^{3}$ cheng@ydu.edu.tw \\ $4^{*}$ Corresponding Author, Department of Leisure Management, Yu Da University of Science and Technology, \\ Taiwan \\ 4*dar5858@yahoo.com.tw
}

\section{ABSTRACT}

In modern society, people face expedited information communication, fast-paced life, and high-pressure work. People are eager for the natural environment of relaxation. The government in Taiwan has paid special attention to the development of leisure agriculture. Events that incorporate farm landscape and agriculture have been held, and rural living has been promoted. Through public engagement and experience, it is expected that agriculture can be promoted into a leisure industry with unique recreational features, in order to bring in additional incomes for the farmers, drive the regional economic development, elevate the living standards of the farmers, promote employment, protect and develop rural culture, and realize ecological conservation.

This paper explores the factors for brand building in leisure agricultural area, and treats Chiang Ma Yuan Recreational Farm Area in Dahu Township, Miaoli County, as the target. Literature review was first conducted to develop the semi-open questionnaire. Then modified Delphi method was adopted for expert interviews, in order to collect expert consensus, and identify the constructs and elements for the brands in hierarchal analysis.

The results were used to analyze the constructs and elements of brand building in Chiang Ma Yuan Farm Area, and suggest its future development direction.

\section{Indexing terms/Keywords}

Leisure agriculture, brand building, semi-open questionnaire, modified Delphi method

\section{Council for Innovative Research}

\section{Peer Review Research Publishing System}

\section{Journal: INTERNATIONAL JOURNAL OF COMPUTERS \& TECHNOLOGY}

Vol.14, No.7

www.ijctonline.com, editorijctonline@gmail.com 


\section{INTRODUCTION}

According to Chen [1], in a rapidly changing society with transforming life style, the traditional industries need to abandon the original mechanism and method, so as to meet the new social forms and trends, and achieve sustainable operation. For this purpose, agriculture has been incorporated with leisure, tourism, education, and travel to develop a new form of leisure agriculture. Social development and change have led to many civil diseases, such as insomnia, anxiety, and depression. People have a high demand for relaxation in a natural environment. To respond to the civil problems and the dilemma faced by traditional industries, the government in Taiwan has paid special attention to the development of leisure agriculture. Through public engagement and experience, it is expected that agriculture can be promoted into a leisure industry with unique recreational features.

According to Tuan [2], in 1970, with rural industry shrinking, the government and scholars began to plan the changes for utilization of rural resources, namely promoting consumption and agricultural products to visitors of farmland. Decades have passed since the initial implementation in 1970. At present, there are more than 1000 leisure farms in Taiwan. Leisure agriculture industry should meet the future needs of both domestic and foreign markets, attract different groups of visitors, and achieve sustainable operation. In the future, leisure agriculture would develop toward 12 aspects of ecology, vacation-use, integration, health-oriented, fineness, visitor experience, legality, unique features, internationalization, efficiency, knowledge, and regionalization.

According to the website [3] of Chiang Ma Yuan Farm Area, it is situated at Guandao Mt. in Lilin Village, Dahu Township, Miaoli County, at an elevation of $500-800 \mathrm{~m}$. This area was known for ginger planting. The quality and quantity of ginger output were highly recognized. This area was called "Chiang Ma Yuan", which was a formal name accepted by the public and government. This area cultivates various vegetables and fruits all year round, such as strawberry, peach, plum, grafted pear, and citrus. Covering an area of about 240 hectares, this leisure agriculture area is connected to Provincial Highway No. 3 in the east and close to Sanyi Interchange, It is conveniently located. Under the promotion of Miaoli County Government, it was voted "Top 10 Villages of Taiwan" by the central government.

The purposes of this study is to summarize the results, limitations and difficulties, propose suggestions on research direction, and offer suggestions for policy maker of this leisure agriculture area.

\section{LITERATURE REVIEW}

This section discusses the literature related to brand and research method, analyzes the elements, steps and research tools of brand building. The content is divided into the following three items:

\section{Elements and steps of brand building 2.1}

Regarding discussion of previous studies, the elements are summarized as follows: (Table 1)

Table 1. Elements and steps to establish the brand

\begin{tabular}{|c|c|l|}
\hline \multicolumn{2}{|c|}{ Elements and steps to establish the brand } \\
\hline Source & Years & \multicolumn{1}{|c|}{ Content } \\
\hline Kolter[4] & 1994 & $\begin{array}{l}\text { 3 steps to build the brand: Select the name of the establishment of the } \\
\text { association, brand positioning and preference }\end{array}$ \\
\hline $\begin{array}{c}\text { Li Ruo Re } \\
\text { Jiun Tzuen [5] }\end{array}$ & 1999 & $\begin{array}{l}\text { Establish the elements of the brand 8: Marketing and product image, business } \\
\text { conditions, the brand names, product design and innovation, the market, business } \\
\text { trends, the enterprise value chain, product copy }\end{array}$ \\
\hline $\begin{array}{c}\text { Keller[6] } \\
\text { Juang Fu } \\
\text { Shiuan[7] }\end{array}$ & 2001 & $\begin{array}{l}\text { Establish the brand targets 6: Image characteristics, evaluation, experience, } \\
\text { performance, resonance }\end{array}$ \\
\hline $\begin{array}{c}\text { Chen Wen } \\
\text { Wen Bin [8] }\end{array}$ & 2003 & $\begin{array}{l}\text { 5 steps to build the brand: Brand (innovation), the brand promise, brand culture } \\
\text { (brand promise), brand blueprint (brand planning), brand evaluation (Brand) }\end{array}$ \\
\hline $\begin{array}{c}\text { Pan Jr Yuan } \\
\text { Yuan [9] }\end{array}$ & 2003 & $\begin{array}{l}\text { Methods of Brand 3: Build brand image, to borrow the extension to other brands, } \\
\text { the acquisition of other brands }\end{array}$ \\
\hline $\begin{array}{c}\text { Schultz \& } \\
\text { Barnes [10] }\end{array}$ & 2003 & $\begin{array}{l}\text { Establish the elements of the brand 4: Brand message, brand contacts, brand } \\
\text { association, brand links }\end{array}$ \\
\hline $\begin{array}{c}\text { Chen Bo } \\
\text { Tsang [11] }\end{array}$ & 2005 & $\begin{array}{l}\text { Establish the elements of the brand 4: Brand symbol, the core brand message, } \\
\text { brand personality, brand core values }\end{array}$ \\
\hline
\end{tabular}




\begin{tabular}{|c|c|l|}
\hline Melin[12] & 2005 & $\begin{array}{l}\text { 6 steps to build the brand: Brand loyalty, brand positioning, core values, brand } \\
\text { recognition, product characteristics, marketing communications }\end{array}$ \\
\hline $\begin{array}{c}\text { Srinivasan, R. } \\
\text { \& Murthy, A. } \\
\text { K[13] }\end{array}$ & 2008 & $\begin{array}{l}\text { Establish the elements of the brand 7: Dissemination of communication, internal } \\
\text { marketing, brand positioning, brand quality, brand experience, reliability, long-term } \\
\text { perspective }\end{array}$ \\
\hline $\begin{array}{c}\text { Gu Ming Huei } \\
\text { [14] }\end{array}$ & 2009 & $\begin{array}{l}\text { Conditions for the establishment of the brand 3: Advantages (design and cost), } \\
\text { product innovation, product positioning and marketing channels }\end{array}$ \\
\hline $\begin{array}{c}\text { Lai Tai Chiuan } \\
\text { [15] }\end{array}$ & 2009 & $\begin{array}{l}\text { Establish the elements of the brand 7: Product characteristics, core values, brand } \\
\text { positioning, brand identity, communication communication, internal brand marketing, } \\
\text { consistency }\end{array}$ \\
\hline $\begin{array}{c}\text { Chiou Jr } \\
\text { Sheng [16] }\end{array}$ & 2009 & $\begin{array}{l}\text { 4 steps to build the brand: Product build, brand positioning, brand trust, brand } \\
\text { loyalty }\end{array}$ \\
\hline $\begin{array}{c}\text { Tsai Cheng } \\
\text { Shian [17] }\end{array}$ & 2011 & $\begin{array}{l}\text { Establish the elements of the brand 5: Target brand positioning, brand name and } \\
\text { image, brand channels, brand management, brand trust and equity }\end{array}$ \\
\hline $\begin{array}{c}\text { Yang Jr Bin } \\
\text { [18] }\end{array}$ & 2013 & $\begin{array}{l}\text { Strategy to establish the brand 4: Customer relationship management strategy, } \\
\text { market entry strategy, pricing strategy, channel strategy }\end{array}$ \\
\hline
\end{tabular}

\section{Delphi method and modified Delphi method 2.2}

Delphi method was first proposed in 1950, for making predictions under limited conditions. According to Linstone \& Turoff [19], the Delphi method was developed by RAND Corp. in order to quantify and predict problems under insufficient information and unclear situation. Expert opinions are collected to analyze and deduce the future events. During the discussion, the importance and opinion of each element is viewed equally, and each member may fully express and discuss their opinions, in order to reach a consensus on the mostly probable or suitable event.

Murry and Hammons [20] suggested that the process Delphi method is time-consuming and difficult to control, thus causing obstacles in reaching a consensus. Moreover, the test process is also time-consuming and contradictions in views may arise. The modified Delphi method removes the open questionnaire, conducts a thorough literature review, and develops a structural questionnaire after expert discussion, so as to solve the problems in time, progress, and reaching consensus.

\section{RESEARCH METHOD}

This study analyzed the brand building of Chiang Ma Yuan Farm Area, and discussed the elements to be considered in brand building. The findings are expected to provide reference on farm area promotion, development of future tourism policy, orientation of future studies, and enhance the tourism quality of the farm.

\section{Research Process 3.1}

The research process is divided into three parts. The elements and constructs of brand building are determined, and expert interviews are conducted to reach a consensus. (Figure 1).

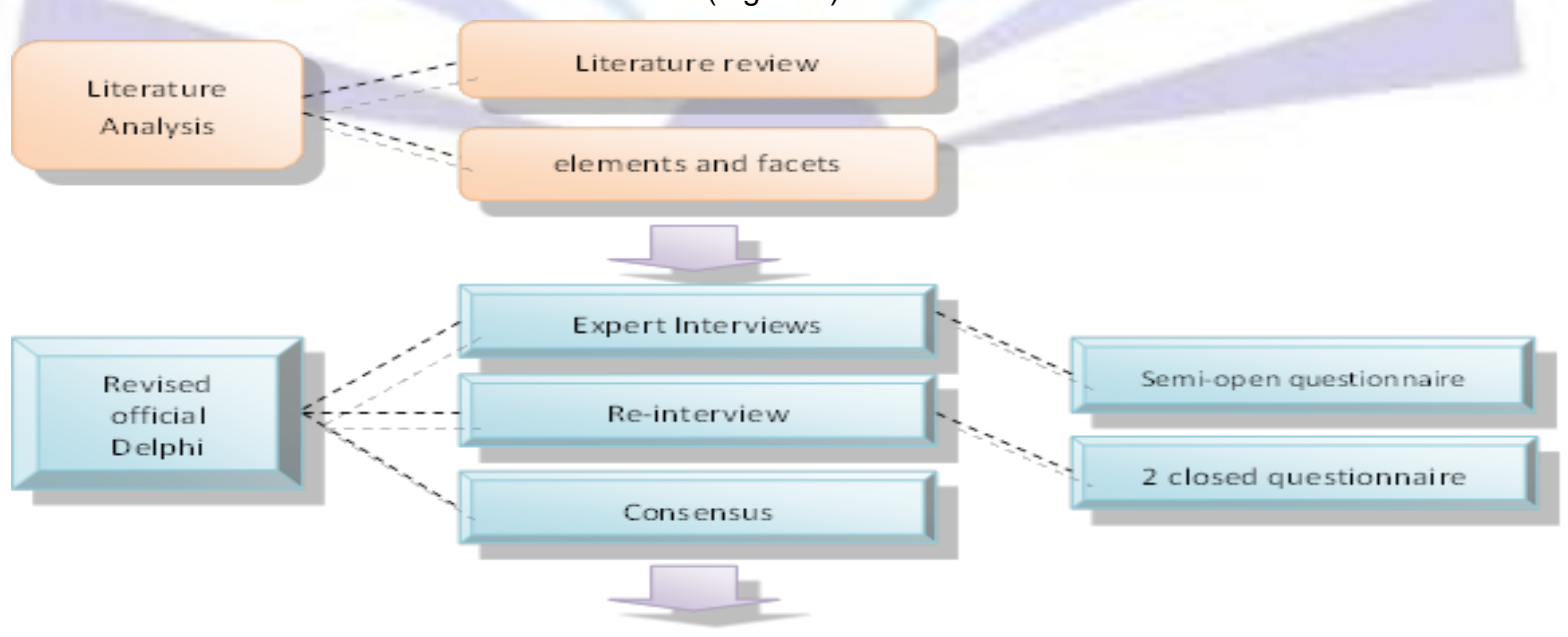

The results

Fig 1: Research flowchart 


\section{Respondents 3.2}

The expert panel of the modified Delphi method is selected as below: (Table 2)

Table 2. Delphi method to repair a formal interview with an expert inventory

\begin{tabular}{|c|c|c|}
\hline \multicolumn{3}{|c|}{ Delphi method to repair a formal interview with an expert inventory } \\
\hline Do industry & Position & Number of people \\
\hline \multirow{2}{*}{ Travel } & Trip planning and business contractors & 1 \\
\hline & Leader, guide & 1 \\
\hline \multirow{2}{*}{ Tourist park } & Planning, design, events and other services & 1 \\
\hline & Field service, reception, tour and commentator & 2 \\
\hline Bodies, agencies & Leisure and tourism-related business contractors & 1 \\
\hline \multirow{2}{*}{ Tourism } & Decision-making, management, and other sectors & 1 \\
\hline & Field service, hospitality, service and sales staff & 2 \\
\hline
\end{tabular}

The panel selection follows the inclusion criteria of experts for the modified Delphi method. The experts are limited to those in Miaoli County.

\section{Interview questionnaire 3.3}

The questionnaire used in this study includes a modified Delphi questionnaire.

1) Semi-open questionnaire

Based on the literature review, a semi-open questionnaire was developed. Experts were invited to add, remove, or modify the constructs and elements. Based on the results, there were 6 constructs and 26 elements.

2) The first round closed questionnaire

The screening standard of the first round questionnaire is that the average value is above 3 and CV value is below 0.5. After questionnaire was retrieved, the data were analyzed to tabulate the statistical table. The results were used to develop the second round questionnaire. Based on the results, there were 5 constructs and 20 elements.

3) The second round closed questionnaire

The screening standard of the third questionnaire is that the average value is above 4 and CV value is below 0.3 . After questionnaire was retrieved, the data were analyzed and tabulated into the statistical table. Based on the results, there were 4 constructs and 16 elements.

\section{RESULTS AND ANALYSIS}

This study used literature review, modified Delphi method, and the weights of the elements are ranked.

After questionnaire distribution, retrieval, and analysis, this study selected 4 constructs and 16 indicators that are considered important by the experts (as shown in Table 3). 
Table 3. Brand building elements - eventually established indicators

\begin{tabular}{|c|c|c|c|}
\hline \multicolumn{4}{|c|}{ Brand building elements - eventually established indicators } \\
\hline Facets & Establish the elements & Facets & Establish the elements \\
\hline \multirow{4}{*}{$\begin{array}{l}\text { Product } \\
\text { dimensions }\end{array}$} & Strengthen product innovation & \multirow{4}{*}{$\begin{array}{c}\text { Facets } \\
\text { marketing } \\
\text { strategy }\end{array}$} & Adopt integrated marketing \\
\hline & Establish product features & & Adopt marketing \\
\hline & Stable product quality & & Take Internet Marketing \\
\hline & Enhance product functionality & & Adopt pricing strategies \\
\hline \multirow{4}{*}{$\begin{array}{l}\text { Brand } \\
\text { Facets }\end{array}$} & Strengthen the brand personality & \multirow{4}{*}{$\begin{array}{l}\text { Enterprises } \\
\text { to Facets }\end{array}$} & Grasp the pulse of the market and trends \\
\hline & Brand image & & Other sister brand extension \\
\hline & Establish brand positioning & & Other well-known brand acquisitions \\
\hline & Establish the brand's core values & & Copy the successful brand and product \\
\hline
\end{tabular}

The expert panel of this study was those with experiences in decision making, management, and operation of the leisure travel industry, or those who emphasize on research, teaching, and publication of leisure travel studies, and have visited, heard about, or have had knowledge about Chiang Ma Yuan Farm Area in Dahu Township, Miaoli County. Surveys were conducted to identify the constructs and elements of brand building for the farm.

\section{Research Contribution and for Development Strategy Suggestions}

Based on literature review, this study designed semi-open questionnaires, and used the modified Delphi method to collect expert opinions, to identify 4 important constructs and 16 elements: 1) product construct: strengthen the product innovation, establish the product characteristics, stabilize the product quality, and enhance the product functions; 2) brand construct: strengthen the brand personality, build the brand image, establish the brand orientation, and establish the brand core values; 3) marketing strategy construct: adopt the integrated marketing, market-oriented marketing, network marketing, and price strategy; 4) marketing strategy construct: grasp the market trends, extend other sister brands, merge other famous brands, and copy the successful brands and products.

The following suggestions are proposed on leisure agriculture development:

1. Establish the product characteristics

When a market is formed for a product, there are numerous competitors and high product homeomorphism. Thus, it is difficult to maintain a fixed market and position. Therefore, product should be differentiated to create its own market share.

2. Strengthen the brand personality

To establish a brand, it is important to build the brand personality, so that the consumers will be emotionally attached. The uniqueness of the branch can manifest its features and concepts, thus enhancing the brand value.

3. Build the brand image

The brand image greatly influences the consumption orientation of consumers and drives their purchasing behavior, so that the consumers will have a subjective interpretation to the brand and have a belief in their minds, which is the brand knowledge. When brand knowledge is deeply rooted, consumers develop brand royalty, thus ensuring the lasting effect of the brand.

4. Stabilize the product quality

People make purchases based on needs, and select the brand based practical reasons. The actual purchase behavior is based on the balance between value and recognition. Thus, stable product quality is the key to brand building, which can ensure the quality and solidify consumer trust, thereby further driving the purchase intention.g. 


\section{REFERENCES}

[1] Chen Jau Lang.1996. 《Leisure Agriculture Handbook》, Council of Agriculture,p1-20.

[2] Duan Jau.2007. Agricultural policy and agricultural condition, Review of Taiwan leisure agriculture development and future development strategy,p177.

[3] Miaoli County, Ma Ginger Garden website,2012,http://130.org.tw/?ptype=info

[4] Kotler, Philip.1994.Marketing Management : Analysis, Planning,Implementations, and Control, Englewood, Cliff, New Jersey : Prentice-Hall.

[5] Li Ruo Re Jiun Tzuen .1999. Business strategy research to establish the brand furniture industry, Institute of Forest Science, National Taiwan University, Thesis, Taipei.

[6] Keller, K. L..2001. "Building Customer-Based Brand Equity " Marketing Management 10(2): 14-19.

[7] Juang Fu Shiuan.2003. Research Library of brand management strategy - A Case Study in Taipei Public Library, National Taiwan University of Library and Information, Thesis, Taipei.

[8] Chen Wen Wen Bin .2003.Brand positioning and marketing strategy to build brand equity - a bicycle to explore the Chinese market, for example Taiwan, National Taipei University Department of Business Administration,Thesis, Taipei.

[9] Pan Jr Yuan Yuan.2003.Research strategy for the operation of the gaming companies online gaming brand, Soochow University, Department of Business Administration,Thesis, Taipei.

[10] Chen Bo An 、 Guo Chiung Li 、 Tseng Tzeng Huei Chi (Translate) .2003.Schultz, Don E. \& Beth E. Barnes , Brand Strategy , Taipei: Five Southern Book。

[11] Chen Bo Tsang (Translate) .2005.Mike Moser B Brand Map: Five steps to create a brand, p14 、20。Taipei : Classic Communications。

[12] Melin, F..2005. A to Z of Management Concepts \& Models; 48-53.

[13] Srinivasan, R. \& Murthy, A. K. .2008. Integrated brand building process : a special case, International Journal of Business Research,8 (3), 174-181.

[14] Gu Ming Huei .2009.Core competitiveness and openness to innovation, research establishment of international brands in the - in Amtran Technology Case Study, Management, University of Science and Technology, Corning, Thesis, Taipei.

[15] Lai Tai Chiuan .2009. The key factor affecting the establishment of the brand - a single malt whiskey in the Taiwan market, for example,Fu Jen Catholic University International Entrepreneurship and Management Department of Management, Thesis, Taipei.

[16] Chiou Jr Sheng .2009.Scroll bar! Brand TW! Taipei, World Vision.

[17] Tsai Cheng Shian .2010.Preliminary study of the establishment of small-scale private long-term care for the elderly based conservation organization brand Taipei, Soochow University Department of Social Work, Thesis, Taipei.

[18] Yang Jr Bin .2013. Internet marketing research to establish the impact of cosmetics brand - A Case Study of A Company, Feng Chia University Department of E-Commerce, Thesis, Taichung.

[19] Linstone, H. A., \& Turoff, M.1975. The Delphi Study: Technique and Applications.Landon, England: Addison-Wesley Publishing Co.

[20] Murry J.W., and J.O. Hammons.1995. "Delphi: A versatile methodology for conducting qualitative research," The Review of Higher Education, vol. 18, no. 4, p. 423-436.

[21] Saaty, T. L..1980. The Analytic Hierarchy Process, N.Y.: McGraw - Hill.. 